\title{
SALES FORECASTING OF PHARMACEUTICAL 'PRODUCTS USING ASSOCIATION RULE MINING (ARM) METHOD
}

\author{
Riska Dhenabayu ${ }^{[1]}$, Ryan Ahmad Syah Putra ${ }^{[2]}$ \\ Faculty of Informatics Enggeenering \\ Email: ${ }^{[1]}$ dhenabayu@unisbablitar.ac.id, ${ }^{[2]}$ ryan.ahmadsyah04@gmail.com
}

\begin{abstract}
This forecasting application can be applied to the pharmaceutical industry including the PPNI Wlingi pharmacy, which sells a variety of over-the-counter and prescription drugs and medical devices. The purchase of over-the-counter drugs is recorded daily. This, if left unchecked, will caused an accumulate sales data without any utilization of these data. Instead, the data can be used to determine the inventory turn over of goods so that it is useful in future sales strategies. One method that can be used is the Association Rule Mining (ARM) method which implement association rules. Association rule can be used to predict patterns of interrelationship between items that are often purchased by customers. The result will make it easier for companies to make the decision to increase or decrease the stock so that the inventory turn over will be shortened and reduce the risk of innefficient accumulation of goods.
\end{abstract}

Keywords : Sales forecasting, pharmaceutical, Association Rule Mining(ARM)

\section{PRELIMINARY}

When the demand increase, the required stock also need to be increased, this will make it difficult for entrepreneurs if there is no clear strategy in selling and stocking pharmaceutical products. The pharmaceutical products in question is medicine such as over the counter drugs and prescription drugs. Sales data can be used as material to predict what items will often be purchased by processing sales data in the past.

Sales data that has been processed will produce valuable information for the company. This information will later become a reference for determining future strategies in sales according to human needs.

Human needs for drugs make it often purchased as a cure when they are sick. This makes the drug stock become erratic. This is supported by the results of the author's survey, in which of the 4 pharmacies surveyed $50 \%$ had erratic stock because the need for certain 
pharmaceutical products suddenly increased. Furthermore, the drug that is suitable for the customer is not fulfilled. For this reason, it is necessary to process data as a forward analysis so that the stock can be met in accordance with customer needs.

One method that can be used to process the data is using the Association Rule Mining method approach. The Association Rule Mining method is expected to be used to design and implement the application of pharmacy product sales forecasting and testing using Beta Testing.

\section{THEORETICAL FRAMEWORK}

\section{A. Association Rule Mining(ARM) Method}

The basic methodology of association analysis is divided into two stages, namely analysis of high frequency patterns and the process of forming associative rules(Norfiansyah, 2014:79).

\section{Analysis of high frequency patterns}

This stage looks for item combinations that meet the minimum requirements of the support value in the database. The support value of an item is obtained by using the following formula:

Support $(A)=$ Number of transactions containing $A$

\section{Total transaction}

While the value of support for two items is obtained through the formula:

Support $(A, B)=(A \cap B)$ Number of transactions containing $A$ and B

\section{Total transaction}

\section{Formation of association rules}

After all high frequency patterns are found next, an association rule is found that meets the minimum requirements for confidence rules if $A$ is $B$. Confidence value if $A$ then $B$ is obtained by the formula:

Confidence $=P(B \mid A)$ Number of transactions containing $A$ and $B$ 


\section{B. Forecasting}

Forecasting is one way to determine things that will happen in the future through mathematical patterns. Prasetya, Hery and Lukiastuti (2009: 43), define forecasting as an attempt to forecast future conditions through testing events in the past. The essence of forecasting is the estimation of events in the future on the basis of past patterns and the use of policies towards projections with past time patterns. Furthermore, according to Subagyo, Ahmad (2007: 74), forecasting is defined as art and science predicting future events by taking historical data and projecting it with mathematical models. So, forecasting can be interpreted as a way to determine future events with past data that is mathematically projected.

\section{Medicine}

Medicine is one of the human needs to cure illness or reduce the pain suffered. According to Health Law No. 36 of 2009, drugs are materials or alloys of materials, including biological products that are used to influence or investigate physiological systems or pathological conditions in the framework of establishing diagnosis, prevention, healing, recovery, improvement in health and contraception for humans. According to Syamsuni, Haji (2005: 47) medicine is all single ingredients or mixtures that are used by all creatures for the inside and outside of the body to prevent, alleviate, reduce, eliminate and cure diseases.

\section{Beta Testing}

The forecasting of pharmacy product sales using the Association Rule Mining method can be implemented at the Wlingi PPNI pharmacy as a reference in determining the inventory. Beta testing is utilized to test the sales prediction software. Beta testing is done objectively, ie the application is tested directly by the user then answering several questions about the ease and feasibility of the application (Basjaruddin, 2014: 99). 


\section{III.DESIGN AND IMPLEMENTATION}

\section{A. Software Design}

\section{Data Analysis}

Data analysis is used to analyze what attributes are needed to build the application. Attributes are used for the calculation process to produce useful information as a reference for the company. The required attributes is pisted in Tabel 3.1.

Tabel 3.1

\section{Data Attributes For Calculation Methods}

\begin{tabular}{cll}
$\begin{array}{c}\text { Numb } \\
\text { er }\end{array}$ & Data & \multicolumn{1}{c}{ Attribute } \\
\hline 1 & Product & $\begin{array}{l}\text { Product ID, Product Name, Unit, Volume, } \\
\text { Price }\end{array}$ \\
\hline 2 & Sales & $\begin{array}{l}\text { Sales ID, Product ID, Amount of sales, Date } \\
\text { of transaction }\end{array}$ \\
&
\end{tabular}

\section{Flowchart}

Flowchart is a diagram that can be used to describe a procedure or process. Below is the flowchart for the admin system.

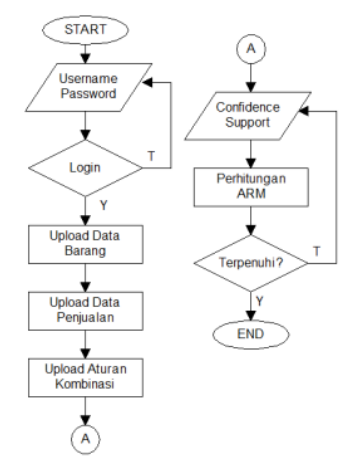

Figure 3.1. Admin System Flowchart 
In accordance with Figure 3.1., the admin flowchart explains that the flow chart starts from the admin inputting the username and password to do the login process. Furthermore, the admin processes the process of adding item data, sales data and combination rules. Admin input the value of support and confidence to carry out the ARM calculation process, if it is appropriate, it is finished and if it is not finished, the input value of support and confidence will return. Next is the ARM method calculation flowchart.

\section{Data Flow Diagram (DFD)}

The Data Flow Diagram (DFD) explains to the user how the flow of system-functions will work. The designed grooves consist of data inputs and processes on diagrams that can be viewed from the system design. There are 2 levels of DFD namely DFD level 0 and DFD level 1.

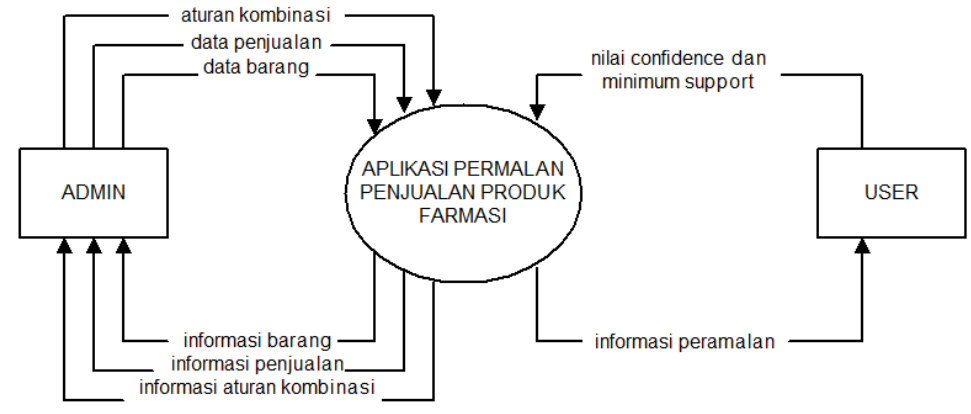

Figure 3.3. DFD Level 0

As shown in the FiGure 3.3. Level 0 DFD contains 2 users and 1 process, namely admin and user and drug sales forecasting process. Admin login with the specified username and password then confirm login. Almost the same as admin, users only see data information and access it. Users only input minimum support values and minimum confidence which are then processed and produce forecasting information or analysis results. 


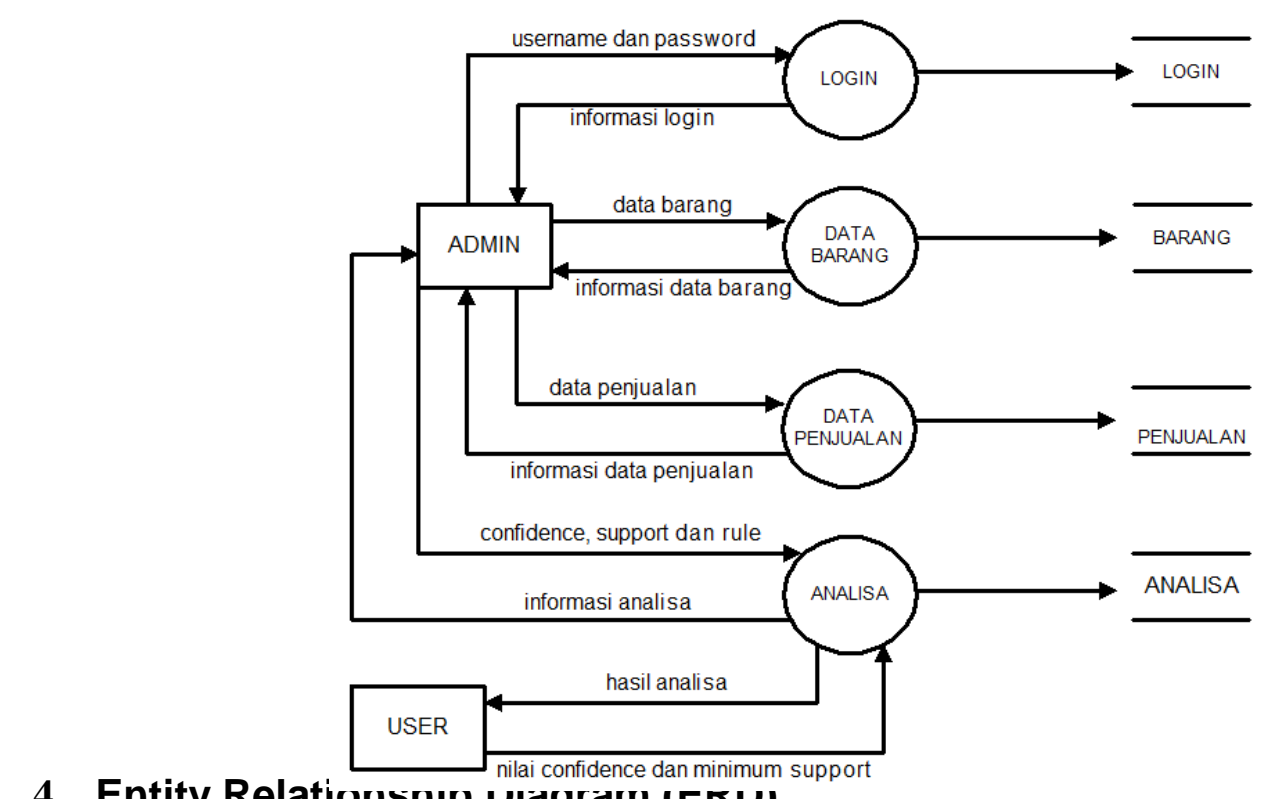

\section{Entity RelatiurısıIp viagradII (cnu)}

Entity Relationship Diagram shows the relationship or relationship between tables so that it forms an information that is easy to understand.

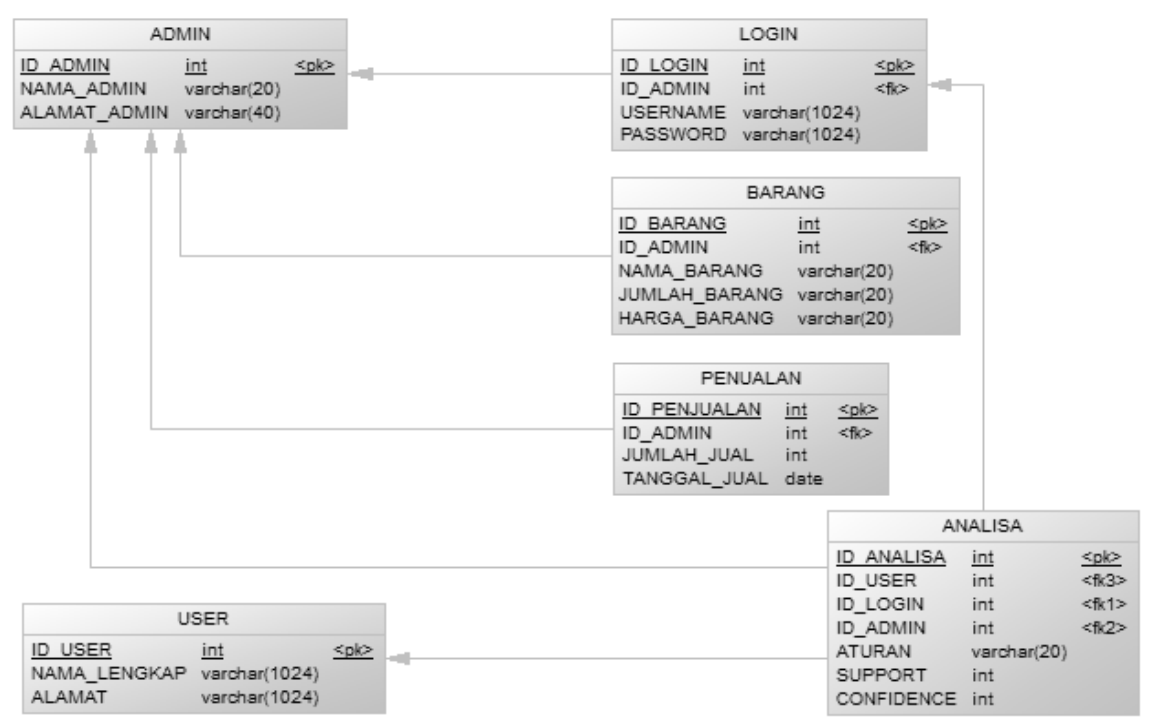


ERD (Entity Relationship Diagram) is always related to a database of a system. ER diagrams are used to determine the relationships between tables in a system database. ERD always has several attributes and uses the primary key as the identity of the table. Table item in Figure 3.5. for example, has a primary key id_barang and has the attribute name_bright, price_bright and number_bright. Furthermore, there is a foreign key as a liaison or relationship between tables.

\section{B. Software User Interface}

\section{Product Data Page}

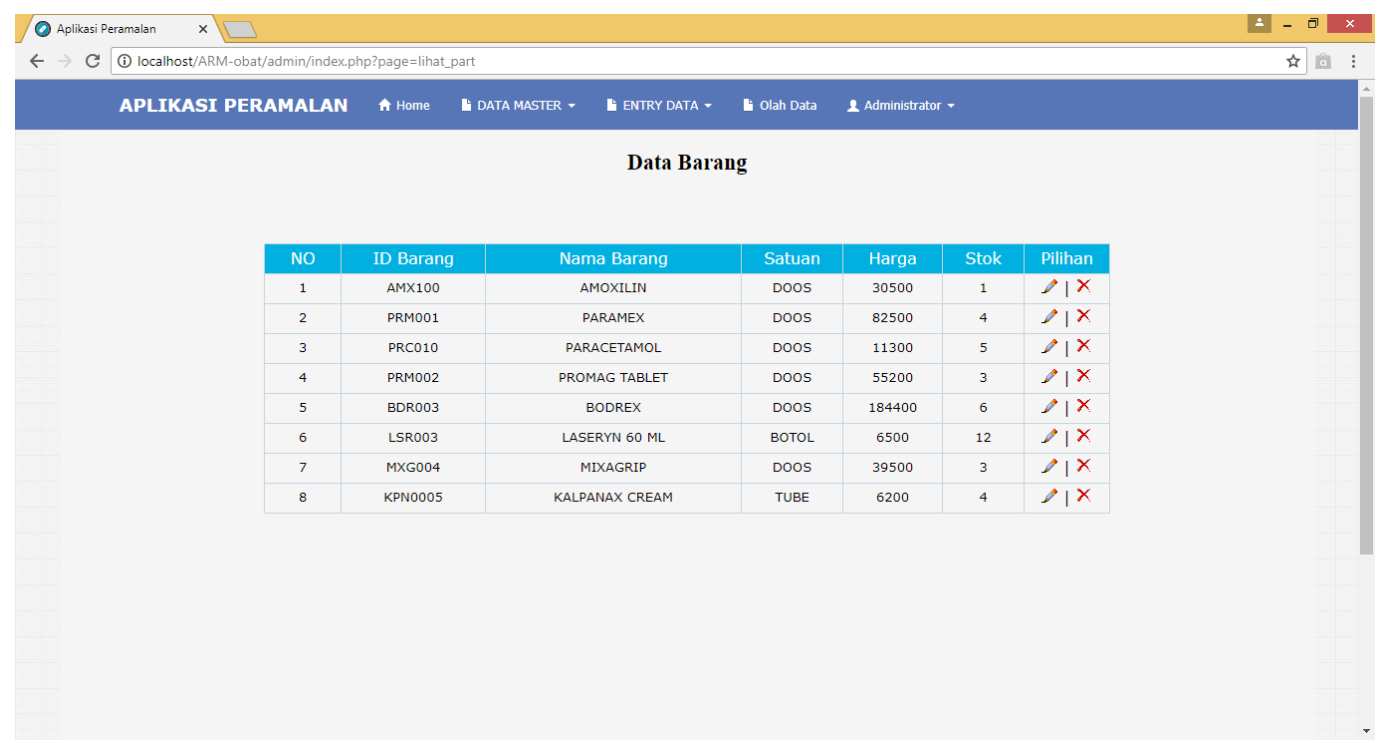

Figure 3.8. Product Data Page

\section{Sales Data Paqe}

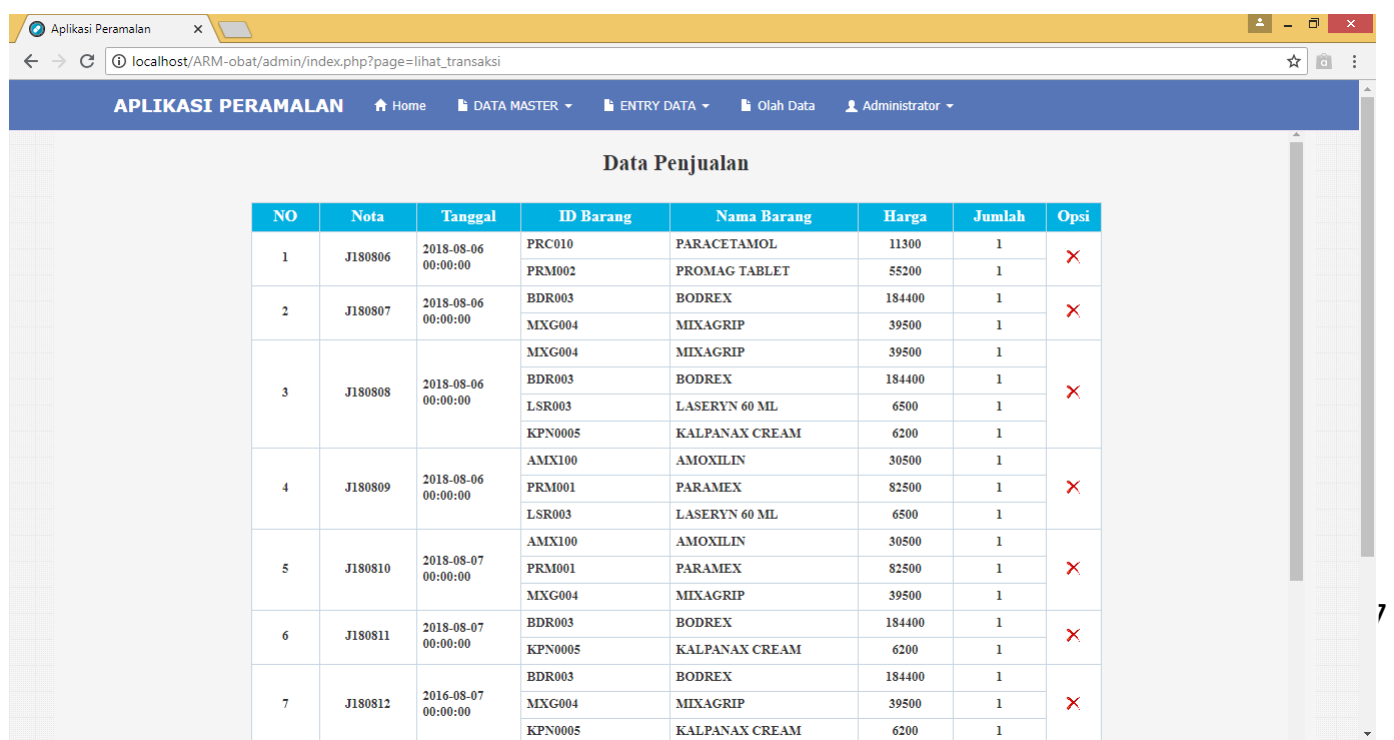

Figure 3.9. Sales Data Page 
JOSAR, Vol. 2 No. 2 September 2017; p-ISSN: 2502-8251; e-ISSN: 2503-1155

Copyrights@ Balitar Islamic University, Blitar-Indonesia https://ejournal.unisbablitar.ac.id/index.php/josar

4. Data Input Page

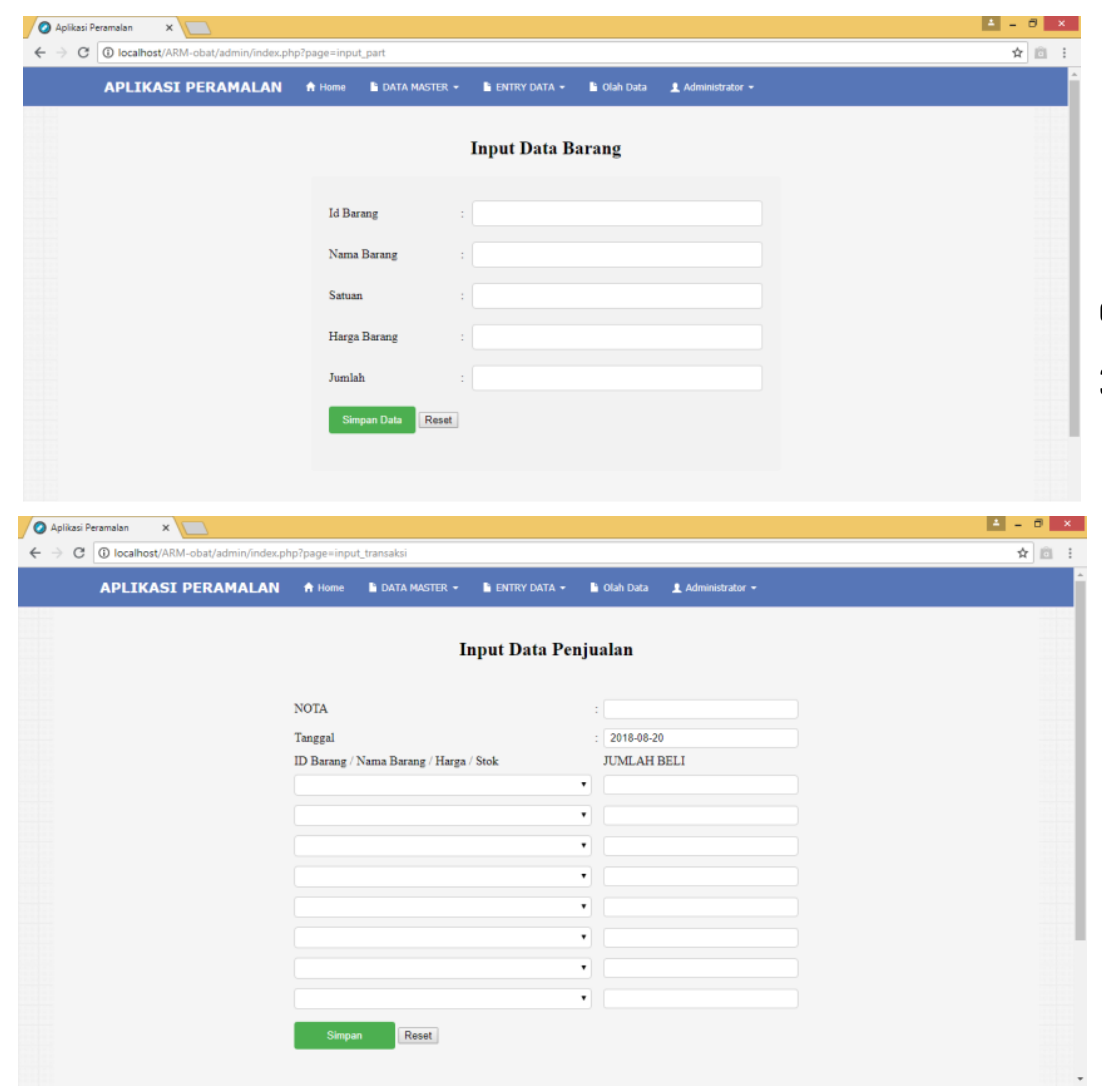

Figure 3.11. Sales Data Input Page

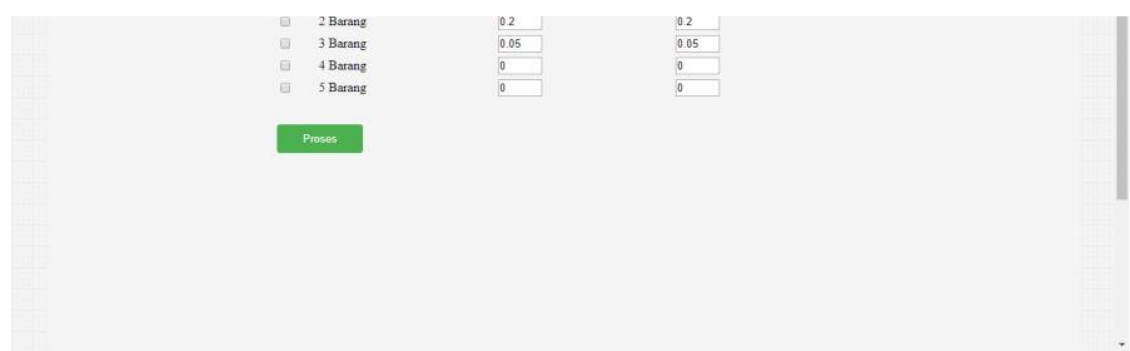

Figure 3.12. Data Processing Page

Furthermore, after the user enters the minimum value of support and confidence, a table will appear containing the processed goods data. In addition, numbers 1 and 0 will appear which indicate a combination of two items. Figure 3.13.and 3.14. are the result page of the data processing. 
JOSAR, Vol. 2 No. 2 September 2017; p-ISSN: 2502-8251; e-ISSN: 2503-1155

Copyrights@ Balitar Islamic University, Blitar-Indonesia https://ejournal.unisbablitar.ac.id/index.php/josar

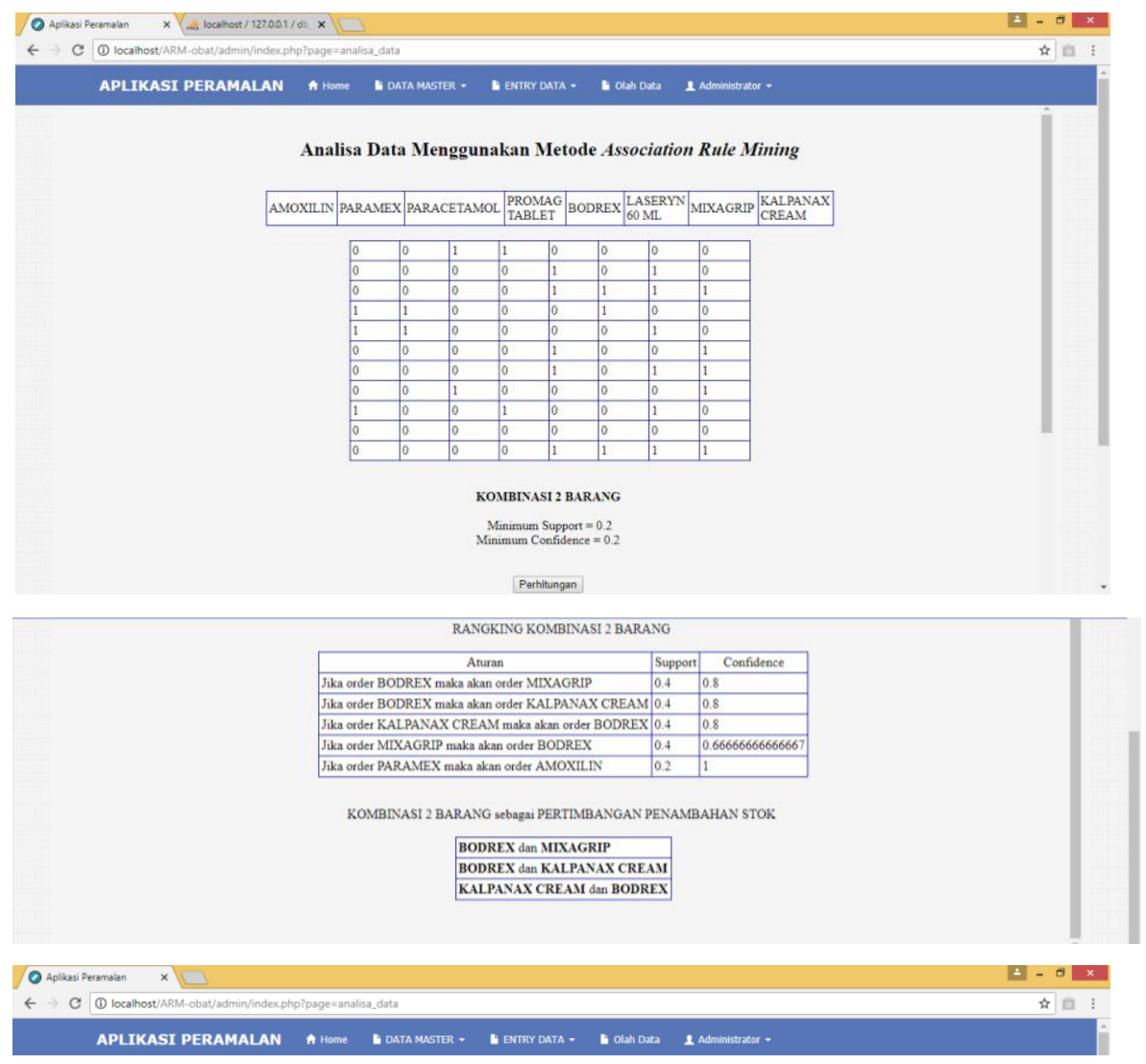

Figure 3.12. RankingResult Page

\section{Data Analysis with Association Rule Mining (ARM) Method}

1. Data Selection

Data selection will be used in the ARM calculation process. In addition, it determines which data you want to use in the calculation process along with the specified attributes. The data used is data taken from August 6 to 092018 with 28 sales data. 


\section{Data Pre-processing}

The data used in this process is data that is clean in the sense that there is no data duplication. So that the data used is consistent data for sampling sales data in accordance with the data that has been obtained. The following Tabel 3.2. is the data used as sample data.

Tabel 3.2.

Sales Sample Data

\begin{tabular}{|c|c|c|c|c|c|c|}
\hline & Nota & Id Barang & Nama Barang & Harga & $\begin{array}{l}\text { Juml } \\
\text { ah }\end{array}$ & Tanggal \\
\hline 1 & J180806 & PRC010 & Paracetamol & 11300 & 1 & $\begin{array}{l}06 / 08 / 20 \\
18\end{array}$ \\
\hline 2 & J180806 & PRM002 & Promag Tablet & 55200 & 1 & $\begin{array}{l}06 / 08 / 20 \\
18\end{array}$ \\
\hline 3 & J180807 & BDR003 & Bodrex & 184400 & 1 & $\begin{array}{l}06 / 08 / 20 \\
18\end{array}$ \\
\hline 4 & J180807 & MXG004 & Mixagrip & 39500 & 1 & $\begin{array}{l}06 / 08 / 20 \\
18\end{array}$ \\
\hline 5 & J180808 & MXG004 & Mixagrip & 39500 & 1 & $\begin{array}{l}06 / 08 / 20 \\
18\end{array}$ \\
\hline 6 & J180808 & BDR003 & Bodrex & 184400 & 1 & $\begin{array}{l}06 / 08 / 20 \\
18\end{array}$ \\
\hline 7 & J180808 & LSR003 & Laseryn 60ml & 6500 & 1 & $\begin{array}{l}06 / 08 / 20 \\
18\end{array}$ \\
\hline 8 & J180808 & KPN005 & Kalpanax & 6200 & 1 & $\begin{array}{l}06 / 08 / 20 \\
18\end{array}$ \\
\hline 9 & J180809 & AMX100 & Amoxilin & 30500 & 1 & $\begin{array}{l}06 / 08 / 20 \\
18\end{array}$ \\
\hline $\begin{array}{l}1 \\
0\end{array}$ & J180809 & PRM001 & Paramex & 82500 & 1 & $\begin{array}{l}06 / 08 / 20 \\
18\end{array}$ \\
\hline $\begin{array}{l}1 \\
1\end{array}$ & J180809 & LSR003 & Laseryn $60 \mathrm{ml}$ & 6500 & 1 & $\begin{array}{l}06 / 08 / 20 \\
18\end{array}$ \\
\hline $\begin{array}{l}1 \\
2\end{array}$ & J180810 & AMX100 & Amoxilin & 30500 & 1 & $\begin{array}{l}07 / 08 / 20 \\
18\end{array}$ \\
\hline $\begin{array}{l}1 \\
3 \\
\end{array}$ & J180810 & PRM001 & Paramex & 82500 & 1 & $\begin{array}{l}07 / 08 / 20 \\
18\end{array}$ \\
\hline $\begin{array}{l}1 \\
4\end{array}$ & J180810 & MXG004 & Mixagrip & 39500 & 1 & $\begin{array}{l}07 / 08 / 20 \\
18\end{array}$ \\
\hline $\begin{array}{l}1 \\
5\end{array}$ & J180811 & BDR003 & Bodrex & 184400 & 1 & $\begin{array}{l}07 / 08 / 20 \\
18\end{array}$ \\
\hline $\begin{array}{l}1 \\
6\end{array}$ & J180811 & KPN005 & Kalpanax & 6200 & 1 & $\begin{array}{l}07 / 08 / 20 \\
18\end{array}$ \\
\hline
\end{tabular}


JOSAR, Vol. 2 No. 2 September 2017; p-ISSN: 2502-8251; e-ISSN: 2503-1155

Copyrights@ Balitar Islamic University, Blitar-Indonesia https://ejournal.unisbablitar.ac.id/index.php/josar

\begin{tabular}{|c|c|c|c|c|c|c|}
\hline $\begin{array}{l}1 \\
7\end{array}$ & J180812 & BDR003 & Bodrex & 184400 & 1 & $\begin{array}{l}07 / 08 / 20 \\
18\end{array}$ \\
\hline $\begin{array}{l}1 \\
8\end{array}$ & J180812 & MXG004 & Mixagrip & 39500 & 1 & $\begin{array}{l}07 / 08 / 20 \\
18\end{array}$ \\
\hline $\begin{array}{l}1 \\
9\end{array}$ & J180812 & KPN005 & Kalpanax & 6200 & 1 & $\begin{array}{l}07 / 08 / 20 \\
18\end{array}$ \\
\hline $\begin{array}{l}2 \\
0\end{array}$ & J180813 & PRC010 & Paracetamol & 11300 & 1 & $\begin{array}{l}07 / 08 / 20 \\
18\end{array}$ \\
\hline $\begin{array}{l}2 \\
1 \\
\end{array}$ & J180813 & KPN005 & Kalpanax & 6200 & 1 & $\begin{array}{l}07 / 08 / 20 \\
18\end{array}$ \\
\hline $\begin{array}{l}2 \\
2\end{array}$ & J180814 & AMX100 & Amoxilin & 30500 & 1 & $\begin{array}{l}08 / 08 / 20 \\
18\end{array}$ \\
\hline $\begin{array}{l}2 \\
3\end{array}$ & J180814 & MXG004 & Mixagrip & 39500 & 1 & $\begin{array}{l}08 / 08 / 20 \\
18\end{array}$ \\
\hline $\begin{array}{l}2 \\
4\end{array}$ & J180814 & PRM002 & Promag Tablet & 55200 & 1 & $\begin{array}{l}08 / 08 / 20 \\
18\end{array}$ \\
\hline $\begin{array}{l}2 \\
5\end{array}$ & J180816 & MXG004 & Mixagrip & 39500 & 1 & $\begin{array}{l}08 / 08 / 20 \\
18\end{array}$ \\
\hline $\begin{array}{l}2 \\
6\end{array}$ & J180816 & BDR003 & Bodrex & 184400 & 1 & $\begin{array}{l}08 / 08 / 20 \\
18\end{array}$ \\
\hline $\begin{array}{l}2 \\
7 \\
\end{array}$ & J180816 & LSR003 & Laseyn 60ml & 6500 & 1 & $\begin{array}{l}08 / 08 / 20 \\
18\end{array}$ \\
\hline $\begin{array}{l}2 \\
8 \\
\end{array}$ & J180816 & KPN005 & Kalpanax & 6200 & 1 & $\begin{array}{l}08 / 08 / 20 \\
18\end{array}$ \\
\hline
\end{tabular}

There are 28 samples of sales data, before entering the transformation process the data is simplified into clean data without data duplication. To simplify grouping, the following Tabel 3.3. is data on drugs that have been filtered.

Tabel 3.3.

Product Sample Data

\begin{tabular}{clllll}
\hline No & Id Barang & \multicolumn{1}{c}{ Nama Barang } & Satuan & Harga & Stok \\
\hline 1 & AMX100 & Amoxilin & Doos & 30.500 & 1 \\
\hline 2 & PRM001 & Paramex & Doos & 82.500 & 4 \\
\hline 3 & PRC010 & Paracetamol & Doos & 11.300 & 5 \\
\hline 4 & PRM002 & Promag Tablet & Doos & 55.200 & 3 \\
\hline 5 & BDR003 & Bodrex & Doos & 184.40 & 6 \\
& & & 0 & \\
\hline 6 & LSR003 & Laseryn 60 ml & Botol & 65.00 & 12 \\
\hline 7 & MXG004 & Mixagrip & Doos & 39.500 & 3 \\
\hline 8 & KPN005 & Kalpanax Cream & Tube & 6.200 & 4 \\
\hline
\end{tabular}




\section{Data Transformation}

Next in Tabel 3.4. is the transformation stage or combining the data into tables so as to form a combination of items according to the data of the drug that has been purchased.

Tabel 3.4.

Data Transformation

\begin{tabular}{|c|c|c|c|c|c|c|c|c|}
\hline & \multicolumn{8}{|c|}{ Nama Obat } \\
\hline Nota & $\begin{array}{l}\text { Amoxili } \\
n\end{array}$ & $\begin{array}{l}\text { Bodr } \\
\text { ex }\end{array}$ & $\begin{array}{l}\text { Param } \\
\text { ex }\end{array}$ & $\begin{array}{l}\text { Para } \\
\text { ceta } \\
\text { mol }\end{array}$ & $\begin{array}{l}\text { Proma } \\
\mathrm{g}\end{array}$ & $\begin{array}{l}\text { Las } \\
\text { eryn }\end{array}$ & $\begin{array}{l}\text { Mixagri } \\
\mathrm{p}\end{array}$ & $\begin{array}{l}\text { Kalpa } \\
\text { nax }\end{array}$ \\
\hline $\begin{array}{l}J 1808 \\
06\end{array}$ & & & & $\checkmark$ & $\checkmark$ & & & \\
\hline $\begin{array}{l}\mathrm{J} 1808 \\
07\end{array}$ & & $\checkmark$ & & & & & $\checkmark$ & \\
\hline $\begin{array}{l}J 1808 \\
08\end{array}$ & & $\checkmark$ & & & & $\checkmark$ & $\checkmark$ & $\checkmark$ \\
\hline $\begin{array}{l}J 1808 \\
09\end{array}$ & $\checkmark$ & & $\checkmark$ & & & $\checkmark$ & & \\
\hline $\begin{array}{l}\mathrm{J} 1808 \\
10\end{array}$ & $\checkmark$ & & $\checkmark$ & & & & $\checkmark$ & \\
\hline $\begin{array}{l}\mathrm{J} 1808 \\
11\end{array}$ & & $\checkmark$ & & & & & & $\checkmark$ \\
\hline $\begin{array}{l}\mathrm{J} 1808 \\
12\end{array}$ & & $\checkmark$ & & & & & $\checkmark$ & $\checkmark$ \\
\hline $\begin{array}{l}\mathrm{J} 1808 \\
13\end{array}$ & & & & $\checkmark$ & & & & $\checkmark$ \\
\hline $\begin{array}{l}\mathrm{J} 1808 \\
14\end{array}$ & $\checkmark$ & & & & $\checkmark$ & & $\checkmark$ & \\
\hline $\begin{array}{l}\mathrm{J} 1808 \\
16\end{array}$ & & $\checkmark$ & & & & $\checkmark$ & $\checkmark$ & $\checkmark$ \\
\hline $\begin{array}{l}\text { Juml } \\
\text { ah }\end{array}$ & 3 & 5 & 2 & 2 & 2 & 3 & 6 & 5 \\
\hline
\end{tabular}

4. Algorithms Calculation Process

a. Support values for one item 
Tabel 3.5.

Support Values For One Item

\begin{tabular}{clll}
\hline $\mathrm{N}$ & Nama Obat & Support & Support $(\mathrm{A})$ \\
0 & & 3 & \\
\hline 1 & Amoxilin & 5 & $3 / 10=0.3$ \\
\hline 2 & Bodrex & 2 & $5 / 10=0.5$ \\
\hline & Paramex & 2 & $2 / 10=0.2$ \\
\hline 4 & Paracetamol & 2 & $2 / 10=0.2$ \\
\hline 5 & Promag & 3 & $2 / 10=02$ \\
\hline 6 & Laseryn & 6 & $3 / 10=0.3$ \\
\hline 7 & Mixagrip & 5 & $6 / 10=0.6$ \\
\hline 8 & Kalpanax & & $5 / 10=0.5$ \\
\hline
\end{tabular}

b. Support values for two items

Tabel 3.6.

Support Values For Two Items

\begin{tabular}{llll}
\hline No & Kombinasi 2 Barang & Support & Support $(A, B)$ \\
\hline 1 & Amoxilin, Paramex & 2 & $2 / 10=0.2$ \\
\hline 2 & Amoxilin, Mixagrip & 2 & $2 / 10=0.2$ \\
\hline 3 & Bodrex, Laseryn & 2 & $2 / 10=0.2$ \\
\hline 4 & Bodrex, Mixagrip & 4 & $4 / 10=0.4$ \\
\hline 5 & Bodrex, Kalpanax & 4 & $4 / 10=0.4$ \\
\hline 6 & Laseryn, Mixagrip & 2 & $2 / 10=0.2$ \\
\hline 7 & Laseryn, Kalpanax & 2 & $2 / 10=0.2$ \\
\hline 8 & Mixagrip, Kalpanax & 3 & $3 / 10=0.3$ \\
\hline
\end{tabular}

c. Confidence values

Tabel 3.7.

Nilai Confidence

\begin{tabular}{lll}
\hline No & Kombinasi 2 Barang & Nilai Confidence \\
\hline 1 & IF buy Amoxilin THEN buy Paramex & $2 / 3=0.667$ \\
\hline 2 & IF buy Amoxilin THEN buy Promag & $1 / 3=0.334$ \\
\hline 3 & IF buy Amoxilin THEN buy Laseryn & $1 / 3=0.334$ \\
\hline 4 & IF buy Amoxilin THEN buy Mixagrip & $2 / 3=0.667$ \\
\hline 5 & IF buy Bodrex THEN buy Laseryn & $2 / 5=0.4$ \\
\hline 6 & IF buy Bodrex THEN buy Mixagrip & $4 / 5=0.8$ \\
\hline 7 & IF buy Bodrex THEN buy Kalpanax & $4 / 5=0.8$ \\
\hline 8 & IF buy Paramex THEN buy Laseryn & $1 / 2=0.5$ \\
\hline 9 & IF buy Paramex THEN buy Mixagrip & $1 / 2=0.5$ \\
\hline
\end{tabular}




\begin{tabular}{lll}
\hline 10 & IF buy Paracetamol THEN buy Promag & $1 / 2=0.5$ \\
\hline 11 & IF buy Paracetamol THEN buy Kalpanax & $1 / 2=0.5$ \\
\hline 12 & IF buy Promag THEN buy Mixagrip & $1 / 2=0.5$ \\
\hline 13 & IF buy Laseryn THEN buy Mixagrip & $2 / 3=0.667$ \\
\hline 14 & IF buy Laseryn THEN buy Kalpanax & $2 / 3=0.667$ \\
\hline 15 & IF buy Mixagrip THEN buy Kalpanax & $3 / 5=0.6$ \\
\hline
\end{tabular}

Tabel 3.7. shown the results of the calculation of confidence values. After determining the minimum support value of 0.2 and confidence of 0.2 , it is found that the value meets the criteria with the highest results.

Tabel 3.8.

\section{Kriteria Hasil}

\begin{tabular}{lll}
\hline Aturan Kombinasi 2 Barang & Support & Confidence \\
\hline IF buy Bodrex THEN buy Mixagrip & 0.4 & 0.8 \\
\hline IF buy Bodrex THEN buy Kalpanax & 0.4 & 0.8 \\
\hline
\end{tabular}

In accordance with Table 3.8., the conclusion is the addition of inventory items must be purchased in these combinations:

1) Bodrex and Mixagrip

2) Bodrex and Kalpanax

\section{Beta Testing Result}

Tabel 3.9. Earned Beta Test Value

\begin{tabular}{llllll}
\hline No & Aspek & SB & B & C & K \\
\hline 1 & Kesesuaian Aplikasi & 30,7 & 56,1 & 13,2 & 0 \\
& & $\%$ & $\%$ & $\%$ & \\
\hline 2 & Kemudahan Aplikasi & $40 \%$ & $54 \%$ & $6 \%$ & 0 \\
\hline
\end{tabular}

Based on the table of beta testing, it can be seen from the appropriateness aspect that the appraisal of good valuation gets a percentage of $56.1 \%$. Furthermore, the ease of application aspects get good value with a percentage of $54 \%$. 


\section{CONCLUSION}

The initial stage of this research was to determine the problems that existed in the Wlingi PPNI pharmacy, namely the accumulation of data that was not utilized. The results of these problems researchers get the application requirements, namely data items and sales data input. In accordance with these data, the researchers designed the flowchart, DFD and ERD as the basis for making the application.

Implementation of the pharmaceutical product forecasting application is made using the PHP programming language based on the website and MySQL database so that it is easily understood and used. Based on the sales data input for three days this application produces a combination of bodrex and mixagrip drugs and bodrex and kalpanax as the final results of predictions of additional drug stock that must be added.

The application of forecasting the sale of pharmaceutical products using the Association Rule Mining (ARM) method has good results. The two aspects tested were the appropriateness aspects of the application which got a percentage of $56.1 \%$ and the ease of application aspects of $54 \%$

\section{REFERENCES}

[1] Subagyo, Ahmad. 2007. Studi Kelayakan Teori dan Aplikasi.Jakarta: PT Elex Media Komputindo.

[2] Norfiansyah, Dicky. 2014. Konsep Data Mining Vs Sistem Pendukung Keputusan. Yogjakarta: Deepublish.

[3] Triyanto, Wiwit Agus. 2014. Association Rule Mining untuk Penentuan Rekomendasi Promosi Produk. Jurnal SIMETRIS. Vol 5: hal 121-126.

[4] Prajapati, Dinesh J. dkk. 2017. Interesting association rule mining with consistent and inconsistent rule detection from big sales data in distributed environment. Science Direct. Future Computing and Informatics Journal 2 (19-30).

[5] Yanto, Robi dan Ririn Khoiriah. 2015. Implementasi Data Mining dengan Metode Algoritma Apriori dalam Menentukan Pola Pembelian Obat. Citec Journal. 
[6] Sholihati, Ira Diana dkk. 2017. Aplikasi Data Mining Berbasis Web Menggunakan Algoritma Apriori untuk Data Penjualan di Apotek. SNATIKA. Vol 4: hal 121-126.

[7] Tampubolon, Kennedi dkk. 2013. Implementasi Data Mining Algoritma Apriori pada Sistem Persediaan Alat-Alat Kesehatan. Informasi dan Teknologi IImiah (INTI). Vol 1:hal 93-106.

[8] Prisila, Evi Nadya dkk. 2014.Implementasi Metode Algoritma Apriori Pada Sistem Pendukung Keputusan Order Barang. Kumpulan Jurnal IImu Komputer (KLIK). Vol 1: hal 46-55.

[9] Syamsuni, Haji. 2005. Farmasetik Dasar dan Hitungan Farmasi. Jakarta: Kedokteran EGC.

[10] Basjaruddin, Noor Cholis. 2015. Pembelajaran Mekatronika Berbasis Proyek. Yogyakarta: Deepublish. 